\title{
The Effect of Good Corporate Governance, Free Cash Flow, and Tax Planning on Earnings Management
}

\author{
Ratno Agriyanto ${ }^{1}$, Azizah Setiyawati ${ }^{2}$, Dessy Noor Farida ${ }^{3}$ \\ Fakultas Ekonomi dan Bisnis Islam Universitas Islam Negeri Walisongo Semarang \\ *Correspondence email: dessy_nf@walisongo.ac.id
}

\section{㟔勒}

ISSN: $1979-4703(\mathrm{p})$

ISSN: 2527-9726 (e)

\begin{tabular}{l}
\hline Article history: \\
\hline Received 7 January 2021 \\
Accepted 27 May 2021 \\
Published 30 June 2021
\end{tabular}

Keywords:

Good Corporate

Governance, Free Cash

Flow, Tax Planning,

Earnings Management

\section{A B S T RA C T}

Earnings is one of the management assessment tools as a form of responsibility to investors, thus allowing opportunistic behavior to do earnings management. The study aims to determine the effect of good corporate governance, free cash flow, and tax planning on earnings management. In this study, the independent variables are the board of independent commissioners, institutional ownership, audit committee, free cash flow, and tax planning. The dependent variable is earnings management which is projected through discretionary accruals using the modified Jones model. Data collected in this study used the documentation method and library method. The object of this study is state-owned companies listed in the 2014-2018 period of the Indonesian Stock Exchange. The sampling technique used purposive sampling, and the analysis technique used multiple linear. This study shows that a partial board of independent commissioners, institutional ownership, audit committee, and tax planning do not significantly affect earnings management. In contrast, free cash flow has a significant negative impact on earnings management. Therefore, implementing good corporate governance, free cash flow, and tax planning which is not just to fulfill existing regulations, will increase performance and company value and trust of investors.

\section{Introduction}

The financial statements aim to deliver information about the financial position, financial performance, and cash flow of the entity that is beneficial for most users of financial statements within making economic decisions and shows the output of management's accountability for the using of resources that have been entrusted (Dewan Standar Akuntansi Syariah-IAI, 2016). Earnings information is one of the components of financial statements. Earnings information is used to measure management's performance, and the efficient use of funds invested in entities manifested in returns and indicators for increasing wealth by interested parties (Agustia, 2013). Therefore, because of the importance of 
earnings in management's assessment as a form of responsibility, opportunistic behavior often arises (Sulistiyanto, 2008). Indications of earnings management bring-off in several state-owned companies in Indonesia within a period are indeed a problem in itself. The financial scandals referred to include:

\section{Table 1.}

List of Companies that Have Been Affected by Earnings Management Cases

\begin{tabular}{ll}
\hline \multicolumn{1}{c}{ Corporate } & Year \\
\hline PT Waskita Karya (Persero) Tbk & 2009 \\
PT Bumi Resources Tbk & 2012 \\
PT Timah (Persero) Tbk & 2015 \\
PT Bank Bukopin Tbk & 2017 \\
PT Garuda Indonesia (Persero) & 2018 \\
Tbk. & \\
PT Asuransi Jiwasraya (Persero) & 2019 \\
\hline
\end{tabular}

Source: Secondary data processed (2020)

The case of PT Garuda Indonesia (Persero) Tbk began when reporting overall economic performance for the economic year 2018 to the Indonesia Stock Exchange, which reported a net profit of USD 809,000. However, two commissioners expressed objections to the report relating to the recording of receivable income by the airline in the form of company profits in the 2018 annual book, where Garuda Indonesia claims a profit of USD 5.01 million from cooperation with PT Mahata Aero Teknologi. Later, the airline was convicted and subjected to fines and obligations to restate financial statements in the 2018 financial year. In its latest report, PT Garuda Indonesia (Persero) Tbk recorded a loss of USD 175.02 million after Mahata's receivables were not included in revenue (JIBI, 2019).
The Jiwasraya case stems from the Supreme Audit Agency (BPK) findings on companies that have made false profits since 2006 through accounting engineering activities (Halim, 2020). In comparison, the problems in Jiwasraya began in 2004 by reporting smaller reserves than they were supposed to reach IDR 2.769 trillion. In 2019, Jiwasraya's managing director said it needed a capital injection of IDR 32.89 trillion to meet the risk-based capital adequacy ratio. The company's assets were recorded at only IDR 23.26 trillion, liabilities were IDR 50.5 trillion, and negative equity was IDR 27.24 trillion. In addition, the problematic JS Saving Plan liabilities amounted to IDR 15.75 trillion, and defaults on JS Saving Plan products reached IDR 12.4 trillion (Sembiring, 2019).

Earnings management is a deliberate control intervention to figure out earnings, usually to meet individual goals. Earnings management practices can erode investor self-assurance within financial reporting and hamper the smooth float of capital on the financial markets (Sutino \& Khoiruddin, 2016). Schipper (1989) in (Nurianah, 2019) explained that earnings management is an intervention with a specific purpose towards a particular process in financial reporting. Conflicts of interest between managers and investors that occur inside the entity can be minimized through tracking mechanisms that aim to align these interests (Gunawan \& Situmorang, 2016).

The monitoring mechanism is carried out through the implementation of good corporate governance (Kusmayadi, 2015). There are three factors within the 
implementation of good corporate governance, namely: a) A specific corporate governance mechanism, consisting of share ownership structure, company financing, auditing, audit committee, board of directors, and management repayment; b) Countryprecise governance mechanisms, consisting of the felony environment, the cultural environment, the preparation of accounting standards, also accounting practices; c) marketplace governance mechanisms, consisting of markets for corporate control, and capital market returns (Kusmayadi, 2015).

An independent board of commissioners is a member of the board of commissioners that does not have economic, management, share proprietorship, and potentially different relationships that can impact to act independently (Rahmawati, 2013). Hayati \& Gusnardi (2012) stated that the independent board of commissioners impacts earnings management. Rahmawati (2013) stated that the independent board of commissioners harms earnings management. At the same time, Kusumawati (2019) stated that the independent board of commissioners has no impact on earnings management.

Institutional ownership is the percentage of shares owned by institutional investors. It influences institutional ownership earnings management (Hayati \& Gusnardi, 2012). Octavia (2017) stated that institutional ownership has a significant positive impact on earnings management. At the same time, Kusumawati (2019) stated that institutional ownership has no impact on earnings management. Free cash flow is cash flow that exceeds the amount needed after the company has funded all relevant working capital projects or investments (Jensen, 1986). Therefore, free cash flow hurts profits management (Agustia, 2013, Rahayu et al., 2018). Meanwhile, the research conducted by Putri \& Rachmawati (2018) stated that free cash flow has no impact on profits management.

Tax planning is a set of strategies to adjust accounting and company finance to reduce tax duties in ways that do not violate applicable taxation rules (Sari et al., 2018). Negara and Suputra (2017) stated that tax planning positively impacts earnings, while Kusumawati (2019) found that tax planning has no impact on earnings management.

Based on the results of research and existing phenomena, this study aims to determine and analyze earnings management, in addition to three organs of good corporate governance, namely the independent board of commissioners, institutional ownership, audit committee, and free cash flow, along with tax planning as independent variables. The implementation of good corporate governance is measured through an independent board of commissioners, institutional ownership, and audit committee. The three variables were independent parties who supervise management to become obstacles for management to carry out earnings management. In addition, other factors that could affect earnings management are free cash flow and tax planning. Free cash flow is used to check the company's financial flexibility through free cash flow analysis. Tax planning is used to see the 
company's strategy in carrying out tax efficiency in financial statements. This research focuses on ongoing public stateowned corporations listed on the Indonesia Stock Exchange from 20142018, which is the latest data until this research is relevant.

\section{Literature Review}

\section{Agency Theory}

The agency problem is a problem that appears due to information asymmetry (Yogi \& Damayanthi, 2016). Agency cost appearance can't be separated from information asymmetry or conflicts of interest between managers and principals. Creating a system that can monitor agents' behavior will lead to agency costs consisting of costs for creating standards, agency monitoring, creation of accounting information systems, and so forth (Anggraeni, 2011). In the view of Islam, opportunistic behavior is certainly not allowed because it betrays the mandate. As contained in the word of Allah, which means: "O you who believe, do not betray Allah and the Apostle (Muhammad) and (also) do not betray the mandates entrusted to you" (QS. AlAnfaal: 27).

In carrying out the employment contract, the agent and stakeholders should maintain the mandate and not betray each other. Therefore, the contractual relationship between the agent and the principal is balanced, systematically showing the optimal implementation of obligations. It is implemented through agents and awards by the principal to the agent to realize the ideal agent-principal relationship. Thus, the contractual relationship is entirely responsible and free from cheating practices, producing valid financial reports. According to Scott in Aditama \& Purwaningsih (2014), there are several motivations for management actions, including providing information to investors, CEO turnover motivation, Initial Public Offering, bonus motivation, debt agreement violation motivation, and tax motivation and political motivation. In addition, Muliasari \& Dianati (2014) research stated that the assessment of earnings management is relevant to Islamic business ethics based on the word of God in Surah An-Nisa verse 135.

Based on Muliasari \& Dianati (2014), a Muslim must testify as he is, even if it can harm himself or his family because that has become a general principle of testimony. Muslims are not limited to testimony only in court but also when a transaction is included in financial reporting. Transactions require symmetrical information between buyers and sellers-no confidential information. This means that Islam's concern is symmetrical information; it should not hide information that allows people to change their minds. In Islamic ethics, the logic must present it as it is. According to Marzuqi \& Latif (2010), Islamic business is a series of business activities in various forms that are not limited to the amount of ownership, including profits, but are limited in obtaining it and using their assets based on Surah Al-Baqarah verse 188.

From the above explanation, Islam considers that managers and accountants must have good characters like honesty, keep the mandate, and be honest in reporting the results of financial 
statements to its users. Honesty is one of the most important capitals in doing business because honesty will avoid harming either party. Thus, Islamic business ethics upholds the spirit of mutual trust, honesty, and justice (Marzuqi \& Latif, 2010).

\section{Good Corporate Governance}

Good corporate governance is a notion that dramatically emphasizes the honor regarding the appropriateness of shareholders to obtain and demonstrate the company's obligation to disclose all data on the corporate's economic performance accurately, timely, and transparently (Fitri, 2018). From an Islamic perspective, there is no standard formula in this regard. However, from the various statements contained in the verses of Koran regarding good corporate governance in the perspective of sharia, it can be constructed, such as in Surah Hud verse 61 and Surah al-Hajj verse 41, which means: "He has created you from the earth (land) which made you so prosper it (build it)." (QS.Hud: 61) and "(Namely) those who, if We affirm their position on the earth, they perform prayers, perform alms, and order to do kindness (amar $m a^{\prime} r u f$ ) and prevent from unjust acts (nabi munkar); and to Allah, all matters return."(QS. Al-Haj): 41).

Based on the two verses above, the first verse explains that human's main mission is to build the earth. Whereas in Surah alHajj verse 41, it is stressed that believers use the power they have to establish prayer, pay zakat and enforce amar ma'ruf nabi mungkar. So, the stance formulated by good corporate governance in Islamic law is the use of authority to manage development oriented to 1) Create a conducive atmosphere for the community to fulfill spiritual needs as symbolized by the enforcement of prayer, $2)$. The creation of prosperity and welfare symbolized through zakat, and 3). The creation of political stability inspired by amar ma'ruf and nahi mungkar (Setyono, 2015).

\section{Free Cash Flow}

Free cash flow is the amount regarding discretionary cash flow that a corporate has. The term free cash flow refers to the cash flow available to be disbursed in conformity with stakeholders after the corporate invests in additional fixed assets; an enlargement of working capital is needed to maintain the company's growth. Free cash flow can be measured through a formula according to Kieso et al. (2007), that is, by calculating between cash flow from operating activities and capital expenditures. Operating Cash Flow (OCF) is cash provided by operating activities that originate from excess cash obtained from cash payments from operating activities, which is set through conversion from an accrual basis to a cash basis. OCF consists of all the company's main activities in making a profit, so depreciation and amortization are not included because they are not cash outflows (Ross et al., 2015). The capital expenditure in question is net working capital, which is obtained from the difference in costs incurred to spend fixed assets minus the cash received from the sale of fixed assets (Ross et al., 2015). The measurement of free cash flow in this study is divided by total assets in the same period. Thus, it can be more comparable for the sample company and its value becomes more relative to the company's 
size.

\section{Tax Planning}

Tax planning is an exertion that encompasses tax planning, so the taxes paid by companies are genuinely efficient. Tax planning organizes individual taxpayers and enterprise entities by utilizing various possibilities of loopholes taken by companies in the corridor of tax regulations so that taxpayers can pay a minimum amount (Pohan, 2013). This study's measurement of tax planning is calculated through tax retention rate, which analyzes the effectiveness of tax management in financial reporting for the current year (Awwaliyah et al., 2019). The calculation of the effectiveness of tax management itself is the calculation of the effectiveness of tax planning (Aditama \& Purwaningsih, 2014). The tax retention rate is obtained by dividing the net income value with profit before taxing in the current year.

\section{Effect of Relationship between Independent Boards of Commissioners on Earnings Management}

The independent board of commissioners is a part of the board of commissioners from the corporate external whose job is to supervise the corporate and act as agent of shareholders. According to agency theory, there are three assumptions about human nature that might be commonly self-centered, have limited thinking power facing the future, and try to keep away from risk. According to this assumption, the manager will act opportunistically for personal interests rather than for common interests and fulfill his principal responsibilities.
The existence of an independent board of commissioners as a form of good corporate governance can reduce irregularities committed by the manager (agent). Some previous studies have shown the same results, including research by Gunawan \& Situmorang (2016), Patrick et al. (2015), Hayati \& Gusnardi (2012), Rahmawati (2013), Octavia (2017), and (Ulum et al., 2020). In comparison, Kusumawati (2019) has found that the independent board of commissioners has no impact on earnings management. Based on previous researches and agency theory, the hypotheses proposed were:

H1: Independent commissioner has a negative effect on earnings management.

\section{Effect of Relationship between Institutional Ownership on Earnings Management}

Institutional ownership is the proportion of business enterprise stocks owned by institutions like investment corporations and other institutions. Institutional investors are assumed to be experienced people and can do better financial analysis to oversee and reduce earnings management practices in the corporate. Based on agency theory, the manager as an agent who the principal gives the mandate and responsibility has to access information more related to the company so that it is prone to be manipulated for the benefit of the agent himself. Therefore, an institutional investor who has more experience and can do better financial analysis will suppress earnings management practices and fraud that the agents may carry out. This is in line with research by Hayati \& Gusnardi (2012), Kusumaningtyas \& Farida (2015) and 
Octavia (2017). Whereas other studies, including research by Rahayu et al. (2018), Kusumawati et al. (2013), and Kusumawati (2019), have shown different things. Based on previous researches and agency theory, the proposed hypothesis is:

$\mathrm{H} 2$ : Institutional ownership harms earnings management

\section{Effect of Relationship between Audit Committees on Earnings Management}

The audit committee is a party that helps the board of commissioners whose activity is to supervise to increase the effectiveness in creating financial disclosure and reporting, compliance with legal guidelines and regulations, and internal control of the corporate (Sulistiyanto, 2008). According to agency theory, the agent who is given the mandate and responsibility in managing the company is certainly demanded by the principal to improve its performance to get high compensation. Therefore, if there is no adequate supervision, it will be vulnerable to being played by agents as if the target is achieved. Thus, it is necessary to have a party given the authority and accountability to prepare financial reporting and observe the internal control system. The task is then delegated to the audit committee.

The results of Kusumaningtyas and Farida (2015), Octavia (2017), and Kusumawati (2019) have shown that the audit committee harm earnings management. In comparison, the results of Gunawan \& Situmorang (2016) and Rahmawati (2013) have shown that the audit committee has no impact on earnings management. Therefore, based on agency theory and previous researches, the proposed hypothesis is:

H3: Audit committee has a negative effect on earning management.

\section{Effect of Relationship between Free Cash Flow on Earnings Management}

Free cash flow with earnings management can be defined in agency theory. In agency theory, one of the causes of issues among management and shareholders is a conflict of interest. One of those conflicts of interest is related to company free cash flow. When free cash flow is in a significant position, management can report lower profits. Free cash flow is used as part of company investment or other forms of funding that management can make (Kusumawati, 2019). A corporation with a significant value of free cash flow tends not to do earnings management. Investors who invest their funds temporarily will focus more on information about the quantity of free cash flow that shows how corporations distribute dividends (Kusumawati, 2019). Research by Agustia (2013) has shown that free cash flow harms earnings management. This is consistent with the research by Rahayu et al. (2018) and Kusumawati (2019), which show that free cash flow impacts earnings management. Meanwhile, Putri \& Rachmawati (2018) research has shown that free cash flow has no impact on profits management. Therefore, based on agency theory and previous research results, the proposed hypothesis is:

H4: Free cash flow has a negative effect on earnings management.

Effect of Relationship between Tax Plannings on Earnings Management 


\section{At-Taqaddum}

Vol. 13 No. 1 (2021) Pg. 1-20

Tax planning relation with earnings management through agency theory. Tax planning arises because there are distinctions in intention between companies and governments. The distinction in intention lies in companies trying to pay taxes to a minimum to reduce the profits they have earned, whereas the government relies on tax payments to address state spending. Thus, the higher the tax-making plans, the greater the business does earnings management. One of the tax plans is by regulating how much of the reported profits are included in earnings management practices. If the profits obtained are high, the company tends to manage earnings to minimize the profits obtained; accordingly, the tax expenses are low (Ayem \& Arifah, 2019).

The results of the research of Ayem \& Arifah (2019), Negara \& Suputra (2017), Kesaulya \& Febriany (2018) have shown that tax planning has a positive impact on earnings management. In contrast, Sari et al. (2018) and Kusumawati (2019) have shown that tax planning had no impact on earnings management. Therefore, based on the agency theory and previous studies' results, the proposed hypothesis is:

H5: Tax planning has a positive effect on earnings management.

\section{Figure 1.}

Theoretical Framework of Thinking

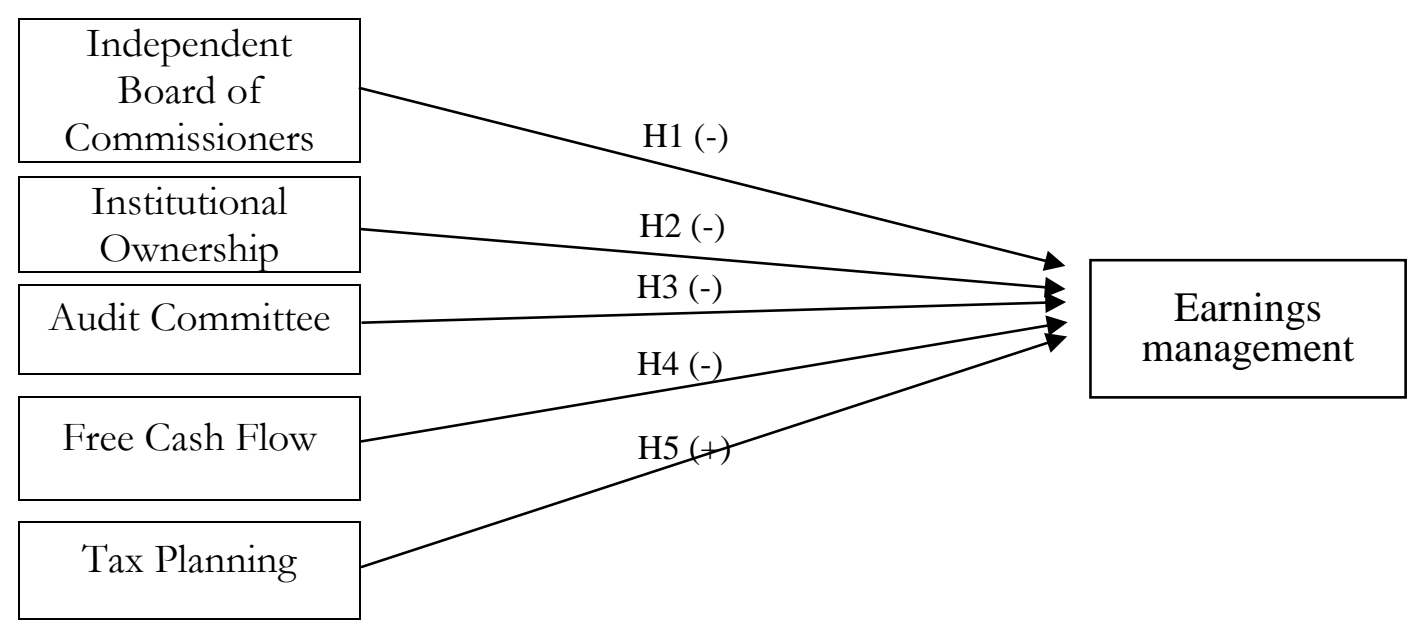

Source: Secondary data processed

\section{Research Method}

The type of this research is quantitative research using multiple linear regression analysis techniques. Data sources were from annual reports, financial reports, and other supporting reports in 20142018. Data was obtained through the Indonesia Stock Exchange website and other sites that support the research, including a state-owned company's 
official website. The population in this research was state-owned corporations listed on the Indonesia Stock Exchange in 2014-2018. Meanwhile, the samples in this study were all state-owned corporations listed on the Indonesia Stock Exchange in 2014-2018. The sampling technique used was purposive.

\section{Table 2.}

Research Samples

\begin{tabular}{lc}
\hline \multicolumn{1}{c}{ Information } & Total \\
\hline State-owned corporations registered on the Indonesia Stock Exchange in & 20 \\
2014-2018 & $(4)$ \\
Corporations that are incompatible and do not have all the data & \\
linked to the variables used in the research & $(3)$ \\
Corporations that do not publish successive financial statements & 13 \\
in rupiah currency & 65 \\
The selected company is the sample & $(28)$ \\
Period 2014-2018 (5 years) = multiplied by 5 & 37 \\
Outlier samples & \\
Number of samples in the study &
\end{tabular}

Source: Secondary data processed (2020)

\section{Research and Measurement Variables}

\section{Dependent Variable}

The dependent variable was earnings management that proxied with discretionary accruals and calculated with a modified Jones model. Discretionary accruals deliberately followed the formula:

$$
\mathbf{T A}_{\text {it }}=\mathbf{N I}_{\text {it }}-\mathrm{CFO}_{\text {it }}
$$

The Total Accrual value calculated by the OLS (Ordinary Least Square) regression equation followed the formula:

$$
\begin{aligned}
& \text { TAit/Ait-1 = } \beta 1 \text { (1/Ait-1) }+\beta 2 \\
& (\Delta \text { Revt/Ait-1) }+\beta 3 \text { (PPEt/Ait-1) }+ \text { e }
\end{aligned}
$$

Meanwhile, the value of nondiscretionary accruals (NDA) is calculated using the formula:

\section{DAit $=$ TAit $/$ Ait-1 - NDAit}

Furthermore Discretionary Accruals (DA) could be calculated as follows:

NDAit $=\beta 1(1 /$ Ait- 1$)+\beta 2(\Delta$ Revt $/$

Ait-1- ectRect / Ait-1) + $\beta 3$ (PPEt /

Ait-1)

Information:

DAit

Discretionary Accruals company $i$ in period $t$

NDAit Non-Discretionary Accruals company $i$ in period $t$

TAit Total Accruals of the company $i$ in period $t$

NI

Net income of company $i$ in period $\mathrm{t}$

CFOit Cash flows from operating activities of the company I in period $\mathrm{t}$ 
Ait-1 Total assets of a company $\mathrm{i}$ in period t-1

$\Delta$ Revt Changes in company income $\mathrm{i}$ in period $\mathrm{t}$

PPEt The company's fixed assets in period $\mathrm{t}$

$\Delta$ Rect Change in company receivables $\mathrm{i}$ in period $\mathrm{t}$

e

error
An independent board of commissioners is a member or board of commissioners who do not affiliate with management, another member of the board of commissioners, controlling stakeholders, and free from all forms of relation that can influence its ability to behave independently (Arintasari \& Rohman, 2015). The IBC passed through the formula:

\section{Independent Variable}

1. Independent Board of Commissioners (IBC)

$$
\text { IBC }=\frac{\text { Number of independent board of commissioners }}{\text { Number of all members of the board of commissioners }} \times 100 \%
$$

2. Institutional Ownership (IO)

Institutional ownership is the total proportion of corporation shares owned by institutions such as investment companies and other institutions. Institutions with shares in the company can monitor and control managers, so the manager can be more focused on the corporation's performance and values to minimize the manager's earnings management towards the corporation. The formula measured institutional ownership in this study:

\section{IO $=\frac{\text { Amount of shares owned by institutional investors }}{\text { Amount of all circulated shares }} \times 100 \%$}

\section{Audit Committee}

The audit committee is the party in charge of supervision to improve effectiveness in creating quality financial disclosure and reporting. According to the Financial Services Authority (OJK) Regulation Article 4 Number 55/POJK.04/2015 concerning the Formation and Guidelines for the Work of the Audit Committee, it is stated that the audit committee includes at least 3 (three) members from Independent Commissioners and parties from outside the issuer (Otoritas Jasa Keuangan, 2015). Therefore, the audit committee is measured using the number of audit committee members in the corporation.

4. Free Cash Flow (FCF)

Free cash flow is calculated by subtracting cash flow from operating activities minus investment divided by the aid of total debt (Jensen, 1986). 
The free cash flow formula is divided by total assets in that same period to be more comparable for the sample company. Its value becomes more relative to the company's size. So according to Rosdini (2009) in Yogi \& Damayanthi (2016), free cash flow is measured by the following formula:

$$
\text { FCF }=\frac{\text { Operating Cash Flow }- \text { Capital Expenditure }}{\text { Total Assets }} \times 100 \%
$$

5. Tax Planning

Tax planning is part of tax management and is the first step in carrying out tax management. Tax planning is measured using the tax retention rate formula, which analyzes the effectiveness of tax management in financial reporting for the current year. Tax planning in this research used the tax retention rate formula by Aditama \& Purwaningsih (2014) as follows:

\section{Tax Retention Rate $=\frac{\text { Net Income }}{\text { Pretax Income }(\text { EBIT })} \times 100 \%$}

\section{Descriptive Statistical Analysis}

Descriptive statistical analysis was carried out to determine the descriptive picture of the variables studied, namely mean, minimum, maximum, and standard deviation of each independent and dependent variable (Hayati \& Gusnardi,
2012). This research's descriptive statistical measurements were carried out using the IBM Statistical Package for Social Science (SPSS) version 23.

The regression analysis equation model developed in this research are:

$$
\mathrm{DA}=\alpha+\beta_{1} \mathrm{IBC}_{\mathrm{it}}+\beta_{2} \mathrm{IO}_{\mathrm{it}}+\beta_{3} \mathrm{AC}_{\mathrm{it}}+\beta_{4} \mathrm{FCF}_{\mathrm{it}}+\beta_{5} \mathrm{TP}_{\mathrm{it}}+\mathrm{e}
$$

Information:

DA discretionary accrual (proxy for earnings management)

$\alpha$

$\beta_{1}-\beta_{5} \quad$ regression coefficient

$\mathrm{IBC}_{\text {it }}$ percentage of independent boards of commissioners in company $i$ in period $t$
$\mathrm{IO}_{\text {it }}$ percentage of institutional ownership in company $i$ in period $\mathrm{t}$

$\mathrm{AC}_{\text {it }}$ percentage of the audit committee in company $i$ in period $t$

$\mathrm{FCF}_{\text {it }}$ percentage free cash flow in company $\mathrm{i}$ in period $\mathrm{t}$ 


\section{At-Taqaddum}

Vol. 13 No. 1 (2021) Pg. 1-20

$\begin{array}{ll}\mathrm{TP}_{\mathrm{it}} & \begin{array}{l}\text { percentage of tax planning in } \\ \text { company } \mathrm{i} \text { in period } \mathrm{t}\end{array} \\ \mathrm{e} & \text { error coefficient }\end{array}$

\section{Result and Discussion}

\section{Description of Research Results}

Earnings management proxied by discretionary accruals $(\mathrm{Y})$ had a minimum value of -0.00428 found in PT Aneka Tambang (Persero) Tbk (2015) and a maximum value of 0.01326 found in PT Pembangunan Perumahan (Persero) Tbk (2016), while the overall average value was 0.0043876. The independent commissioner variable (X1) has a minimum value of 0.2 found in PT Semen Baturaja (Persero) Tbk (2016), while the maximum value was 0.5 found in PT Pembangunan Perumahan (Persero). Tbk (2015) and PT Timah (Persero) Tbk (2016), while the overall average value was 0,3505768 . The institutional ownership variable (X2) had a minimum value of
0,79673 found in PT Waskita Karya (Persero) Tbk (2015), and a maximum value of 0.99984 was in PT Jasa Marga (Persero) Tbk (2014 and 2015), while the overall average score was 0.9252768 .

The audit committee variable (X3) had a minimum value of 2 in PT Adhi Karya (Persero). Tbk (2014) and a maximum value of 5 found in PT Adhi Karya (Persero).Tbk (2017) and PT Wijaya Karya (Persero). Tbk (2018) while the overall average value was 3.6216. The free cash flow variable (X4) had a minimum value of -010737 in PT Adhi Karya (Persero) Tbk (2017), and the maximum value in PT Semen Indonesia (Persero) Tbk (2016) was 0.23165 , while the average was 0.0590414 . The tax planning variable (X5) had a minimum value of 0.51436 in PT Aneka Tambang (Persero) Tbk (2016) and a maximum value of 0.99311 in PT.Adhi.Karya.(Persero). Tbk (2018), while the average was 0.7442368 .

\section{Table 3.}

Summary of Classical Assumption Test

\begin{tabular}{lr}
\hline \multicolumn{1}{c}{ Multicollinearity Testing Results } & Tolerance \\
\hline a. Independent Board of Commissioners & 0.921 \\
b. Institutional Ownership & 0.780 \\
c. Audit Committee & .806 \\
d. Free Cash Flow & 0.718 \\
e. Tax Planning & 0.860 \\
Heteroscedasticity Test Results (Glejser Test) & Sig. T-test \\
a. Independent Board of Commissioners & 0.733 \\
b. Institutional Ownership & 0.805 \\
c. Audit Committee & 0.775 \\
d. Free Cash Flow & 0.745 \\
e. Tax Planning & .801
\end{tabular}


Residual Normality Testing

Kolmogorov Smirnov

Autocorrelation Testing Results

a. The Durbin Watson Test

b. Test Run Test

$\mathrm{N}=37$

Source: Outcome from SPSS (2020)

Based on table 3, the normality test results through the Kolmogorov-Smirnov test show a significance value of 0.200 . Thus, it must be stacked so that the input is normally distributed. While the results of the multicollinearity test show the tolerance value of all variables is close to 1 , while the VIF value is not more than 10 . Thus, each independent variable does not have multicollinearity.

\section{Hypothesis Test}

Coefficient of Determination

\section{Table 4.}

Determination Coefficient Results

\begin{tabular}{lrrc}
\hline Model & R & R Square & Adjusted R Square \\
\hline 1 & $.488 \mathrm{a}$ & .238 & .115
\end{tabular}

Source: Outcome from SPSS (2020)

Based on table 4, the adjusted $\mathrm{R}$ square percentage was $11.5 \%$ or 0.115 . This shows that the independent variable can explain the dependent variable at $11.5 \%$, and then about $88.5 \%$ is clarified by other variables outside this study.

\section{Table 5.}

Test Results $t$

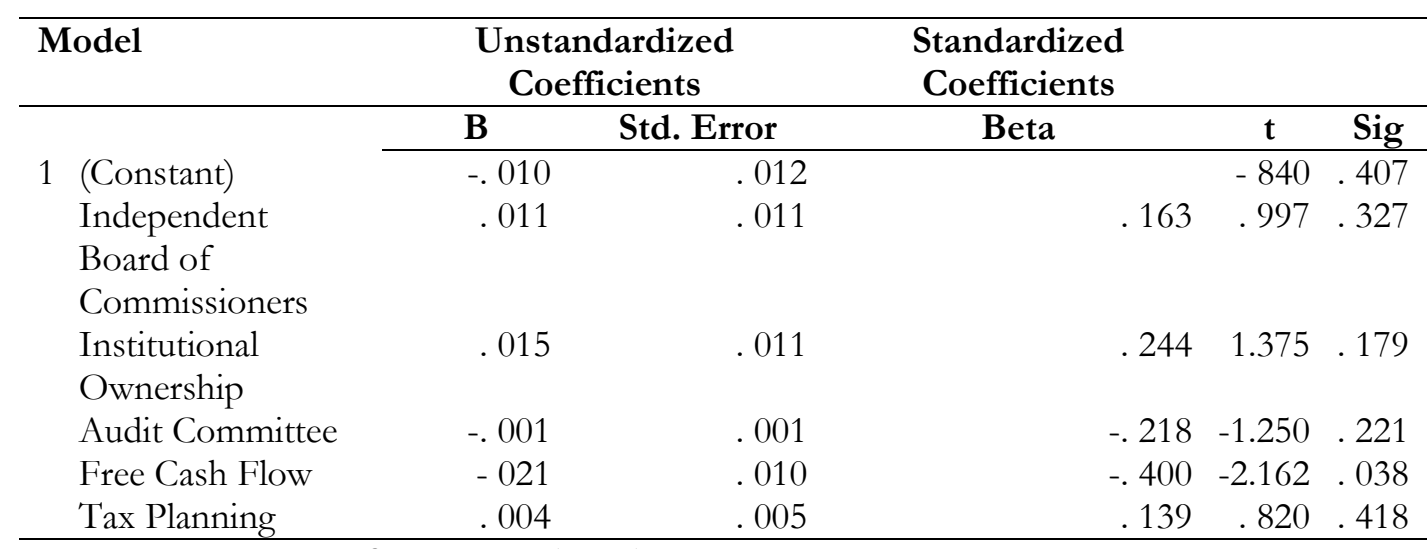

Source: Outcome from SPSS (2020) 


\section{Discussion of Research Results}

\section{The Effect of the Independent Board of Commissioners on Earnings Management}

Hypothesis 1 test outcome from table 5 indicates that the independent commissioner variable does not significantly affect earnings management. This is proven by the $t$ value of 0.997 and the significance value of 0.327 . Thus, it concludes that hypothesis 1 is rejected, which means that the size of the independent board of commissioners has no significant effect on earnings management in SOEs enlisted at the Indonesia Stock Exchange in the 20142018 period.

As one of the principles in implementing good corporate governance, the independent board of commissioners is predicted to act independently and make effective, appropriate, and fast decisions to perform their independence and criticality to uncover earnings management practices (Prabowo, 2018). According to Securities Listing Regulation No. 1-A concerning General Provisions for Registering Equity Securities on the Stock Exchange, the board of commissioners includes two members of the board of commissioners, one among whom is an independent commissioner. If it consists of more than two members of the board of commissioners, then the members of independent commissioners must be at least $30 \%$ from all members of the board of commissioners. However, sometimes these provisions are only made to comply with regulations so that good corporate governance can be realized even though there are not necessarily such guarantees in practice. Thus, the proportion of independent commissioners cannot reduce earnings management practices (Prabowo, 2018)(Prabowo, 2018). The results of this study are in line and consistent with the results of the study of Rahayu et al. (2018) and Kusumawati (2019), which state that the independent board of commissioners does not affect earnings management. That means that the increasing percentage of independent commissioners does not significantly influence earnings management at the corporate.

Thus, the independent board of commissioners cannot control agents to reduce earnings management. Furthermore, the higher the scale of the board of commissioners raises agency problems, such as the more members inside the board of commissioners, the company will have difficulty carrying out its role. For example, communicating and coordinating work among board members, struggling in tracking and controlling agent's actions in making decisions for the corporate. The board of commissioners who have difficulty in carrying out this role will cause a lack of supervision from the board of commissioners on the company's management, which can decrease the company's performance (Rahayu et al., 2018). Furthermore, other possible causes such as transformations in proportion and scale of the board of commissioners in the previous research period caused the performance of the board of commissioners of the research period to be ineffective in carrying out its duties in overseeing and monitoring earnings 
management. In addition, most independent boards of commissioners are based on the results of the GMS elected by the majority shareholder. Therefore, if a decision is not in line with the owner, a change can be made. Therefore, although the percentage of independent commissioners is relatively large, it cannot act independently and supervise.

\section{Effect of Institutional Ownership on Earnings Management}

The outcome of testing the second hypothesis represents that institutional ownership does not significantly influence earnings management, which is proven by the $t$ value of 1.375 and the significance value of 0.179 . Thus, it can be inferred that $\mathrm{H} 2$ is rejected, which means that whether big or small an institutional ownership is, it does not significantly affect earnings management in state-owned companies (BUMN).

The outcome of this research is in line with the results of research by Kusumawati et al. (2013), Kusumaningtyas and Farida (2015), Rahayu et al. (2018), and Kusumawati (2019) that find the institutional ownership has not been able to influence earnings management actions. The outcome of this research shows that institutional investors cannot carry out their role effectively in reducing earnings management. Rahayu et al. (2018) state that institutional ownership has no impact on earnings management. Institutional ownership is the party with large-scale shares ownership that should be expected to control earnings management. Instead, it only focuses on the profits generated so that institutional investors obtain high profits (Rahayu. et al., 2018).

As parties holding considerable shareholdings, institutional investors should have more power to control management to prevent or lessen earnings management activities. But in this situation, institutional investors cannot control the management of the company. This is because institutional investors do not play the role of experienced investors who have more capability and chance to observe and discipline management to focus more on the corporation's grade and restrict agent policies in misusing profits. Still, they only act as temporary owners who focus more on current profits (Kusumawati, 2019).

\section{Effect of the Audit Committee on Earning Management}

The outcome of the testing hypothesis indicates that the audit committee variable does not significantly influence earnings management, which is proven by the calculation of $\mathrm{t}$ value of -1.250 and significance value of 0.221 . Thus, it can be inferred that $\mathrm{H} 3$ can be drawn, which means the size of the audit committee in a company does not affect earnings management in a state-owned company (BUMN).

The outcome of this research is in line with the results of research by Hayati and Gusnardi (2012), Kusumawati et al. (2013), and Gunawan \& Situmorang (2016). They reveal that the audit committee has not been one of the factors that reduce earnings management practices. Build upon the study results indicates that the audit committee as a corporate governance mechanism has no longer been capable of controlling earnings management activities by the management. This shows that the audit committee has not carried out its duties. Based on the Decree of the Minister of State-Owned Enterprises No. Kep- 
$103 / 2002$, the duties and responsibilities of the audit committee include assessing the implementation of the audit and its results, presenting guidelines for improvement, controlling the company's management system and its implementation, ensuring to obtain adequate evaluation methods (Prabowo, 2018).

It could be visible that the audit committee in the company has not carried out its duties properly in carrying out supervision of the company by upholding the principles in corporate governance. This is likely because the research only links the presence of the audit committee and has not tried to prove the impact of the traits of the audit committee members with the type of earnings management. These characteristics are the audit committee's activities (the value of meetings with the function of the Internal Control System and external auditors without the presence of the Directors), financial literacy of audit committee parts, competency of audit committee parts, educational background, experience, etc. Thus this can be explained that the audit committee in the corporate may only fulfill the regulations, but it is not supposed to uphold good corporate governance within the corporate (Hayati \& Gusnardi, 2012).

\section{Effects of Free Cash Flow on Earnings Management}

The testing results show that the free cash flow variable has a significant negative effect on earnings management. This is proven by the $t$ value of $-2,162$ and the significance value of 0.038 . Thus, $\mathrm{H} 4$ conclusions can be drawn, meaning that the increasing value of free cash flow decreases earnings management at stateowned companies (BUMN). In line with
Agustia (2013), Rahayu et al. (2018), and Kusumawati (2019), where free cash flow harms earnings management. The outcome follows the theory that free cash flow affects earnings management. Corporates with high free cash flow tend to reduce the agent's intention to carry out earnings management activities. Free cash flow is the substantive cash flow that may be shared with investors after the corporate has made all the funding. Therefore, working capital has to preserve its operation continuously.

The negative impact is that because free cash flow is a crucial factor in deciding corporate worth, corporate internals focus on efforts to grow free cash flow, which is the most attractive point for investors at the corporation's cash flow data. Cash flow data can show corporate cap potential to distribute dividends. The company has increased share prices at high cash flows because shareholders see that the corporation has extra cash for issuing a dividend. The more the free cash flow glides in the corporate, the wealthier it is because it has cash for growth, debt collection, and returns. This also signifies that the smaller the free cash flow a corporation has, the unhealthier a corporation can be. Because most investors focus more on the corporate's free cash flow data, corporations with high excessive free cash flow values generally tend to no longer control profits (Agustia, 2013).

\section{Effect of Tax Planning on Earnings Management}

The fifth hypothesis testing results show the variable tax planning does not significantly influence earnings management, as proven by the t-value 
calculation of 0.820 and a significance value of 0.418 . Thus, it can be inferred that the $\mathrm{H} 5$ is rejected. That is to say, whether big or small a tax planning is, it has no effect on profits management in stateowned companies (BUMN).

The consequence of the research is in line with the consequence in research by Kusumawati (2019) and Sari et al. (2018), which find that tax planning has not to influence earnings management. These results are due to the single tax rate for corporation taxpayers in 2010 decreasing from $28 \%$ to $25 \%$, so managers cannot maximize opportunities for earnings management. In addition, managers tend to review or modify tax plans that have been made previously (Sari et al., 2018). One of the objectives of tax planning is to use the regulation of how much profit is announced to include it in earnings management practices. In general, tax planning means manipulating a taxpayer's transaction business; thus, the tax bill is in a minimal value but does not violate or against the applicable tax policies. Especially for the time being, although there is a right to do tax planning, it is limited by tax rules that have been systematic and transparent, so it does not affect earnings management practices. Therefore, the existence of tax planning has not to affect earnings management (Kusumawati, 2019).

\section{Conclusion}

Based on the outcomes of testing and data analysis, the conclusion from this study is that the independent board of commissioners shows no significant effect on earnings management in state-owned companies. It is caused by difficulties experienced by members of the board of commissioners. The appointment of an independent board of commissioners is formed due to the shareholders' general meeting. The majority of shareholders elect it. Institutional ownership shows an insignificant influence on earnings management in state-owned companies. The role of institutional ownership causes this to be only as a temporary owner who is more focused on current earnings, thus motivating managers to do profit management in the short term. The audit committee shows an insignificant effect on earnings management because the audit committee has not upheld good corporate governance. After all, there is the possibility that it is only limited to compliance with regulations. Free cash flow shows a significant negative influence on earnings management for state-owned companies. Then the more considerable the amount of free cash flow, the less the practice of earnings management. Tax planning shows the insignificant influence on earnings management for state-owned companies registered at the Indonesia Stock Exchange in 2014-2018. Thus, managers cannot maximize possibilities for profits management due to changes in corporation taxpayer rates.

\section{Recommendation}

Some limitations in this research include the period in the research was only five years, so it is still lack in explaining specifically and comprehensively regarding the influence of variables in the research. Besides that, not all data are included in the research because there are outlier data. Furthermore, this research is limited to companies under state ownership, so many other companies can still change the 


\section{At-Taqaddum}

Vol. 13 No. 1 (2021) Pg. 1-20

conclusions obtained. Nevertheless, through this research, the implementation of good corporate governance, free cash flow, and tax planning could be carried out optimally. In addition, the companies must pay attention to the recruitment process and educational background of an independent board of commissioners and audit committee so that professionals and suitable with their expertise fill the position. Through free cash flow and tax planning, good planning could be carried out so the operational activities could run well. Thus, the implementation for all aspects could be effective and efficient and increase the company's value for stakeholders.

\section{References}

Aditama, F., \& Purwaningsih, A. (2014). Pengaruh Perencanaan Pajak Terhadap Manajemen Laba pada Perusahaan Nonmanufaktur yang Terdaftar di Bursa Efek Indonesia. MODUS, 26(1), 33-50. https://doi.org/https://doi.org/10. 24002/modus.v26il.576

Agustia, D. (2013). Pengaruh Free Cash Flow dan Kualitas Audit Terhadap Manajemen Laba. AKRUAL, 4(2), 105-118.

https://doi.org/https://doi.org/10. 9744/jak.15.1.27-42

Anggraeni, M. D. (2011). Agency Theory Dalam Perspektif Islam. JHI (Jurnal Hukum Islam), 9(2), 1-13.

Arintasari, O. W., \& Rohman, A. (2015). Pengaruh Diversifikasi Industri, Geografis, dan Mekanisme Corporate Governance terhadap Manajemen
Laba. Diponegoro Journal of Accounting, 4(3), 1-13.

Awwaliyah, N. F., Agriyanto, R., \& Farida, D. N. (2019). The effect of regional original income and balance funding on regional government financial performance. Journal of Islamic Accounting and Finance Research, 1(1).

Ayem, S., \& Arifah, P. H. N. (2019). Pengaruh Ukuran Perusahaan, Konvergensi IFRS dan Perencanaan Pajak Terhadap Manajemen Laba (Studi Pada Perusahaan BUMN yang terdaftar di Bursa Efek Indonesia periode 2012-2017). Jurnal Akuntansi Dan Pajak Dewantara, 1(2), 171-180. https://doi.org/10.24964/japd.v1i1. 912

Bisnis.com. (n.d.). Audit BPK terhadap Garuda Indonesia, Ada Temuan Terkait Mahata.

Dewan Standar Akuntansi Syariah - IAI. (2016). PSAK 101 Tentang Penyajian Laporan Keuangan Syariah. In Standar Akuntansi Keuangan Syariah (Issue 1, p. 101.41).

Fitri Hayati, A., \& Gusnardi. (2012). Pengaruh Penerapan Mekanisme Good Corporate Governance Terhadap Manajemen Laba (Studi pada BUMN di Bursa Efek Indonesia Periode 2007-2009). Jurnal Akuntansi, 16(3), 364-379.

Fitri, N. U. (2018). Implementasi Good Corporate Governance (GCG) Dalam Pengelolaan Manajemen Risiko pada BMT-UGT Sidogiri Cabang Pringsewu. In Skripsi Sarjana Studi Perbankan Syariah. UIN Raden Intan Lampung. 
Gunawan, \& Meita Situmorang, E. (2016). Pengaruh Dewan Komisaris , Kepemilikan Manajerial dan Komite Audit terhadap Manajemen Laba pada Perusahaan BUMN di Bursa Efek Indonesia Periode Tahun 20122015. Jurnal Ekonomi, Manajemen Dan Perbankan, 2(2), 55-62. https://doi.org/htpp://dx.doi.org/1 0.35384/jemp.v2i2.102

Indah.R, V., Afrizal, \& Diah P.A, E. (2018). Determinan Manajemen Laba pada Perusahaan BUMN yang Terdaftar di Bursa Efek Indonesia. Jurnal Akuntansi Dan Keuangan UNJA, 3(4), 35-52.

Indonesia, C. (n.d.). Bobrok dari 2004, Ini Kronologi Jiwasraya Hingga Default.

Is'ada Rahmawati, H. (2013). Pengaruh Good Corporate Governance (GCG) Terhadap Manajemen Laba Pada Perusahaan Perbankan. Accounting Analysis Journal, 2(1), 9-18. https://doi.org/https://doi.org/10. 15294/aaj/v2i1.1136

Jensen, M. C. (1986). Agency Costs of Free Cash Flow, Corporate Finance, and Takeovers. American Economic Review, $76(2)$, 323-329. https://doi.org/https://doi.org/10. 1016/0304-405X(76)90026-X

Kesaulya, F. A., \& Febriany, N. (2018). KEBANGSAAN BOARD OF BLOCKHOLDERS TERHADAP NILAI PERUSAHAAN : STUDI PADA PERUSAHAAN PUBLIK DI INDONESIA. Kompartemen: Jurnal Ilmiah Akuntansi, XVII(2), 60 68.

Kompas.com. (n.d.). 5 Fakta Baru Kasus Jiwasraya, Laba Semu bingga Janji Jaksa
Agung Ungkap Tersangka.

Kusmayadi, D. (2015). Good Corporate Governance. LPPM Universitas Siliwangi.

Kusumaningtyas, M., \& Farida, D. N. (2015). Pengaruh Kompetensi Komite Audit, Aktivitas Komite Audit dan Kepemilikan Institusional Terhadap Manajemen Laba. Jurnal Akuntansi Indonesia, 4(1), 66-82. https://doi.org/htpp://dx.doi.org/1 0.30659/jai.4.1.66-82

Kusumawati, E. (2019). Determinan Manajemen Laba: Kajian Empiris Pada Perusahaan Manufaktur Go Publik Di Bursa Efek Indonesia. Jurnal Riset Akuntansi Dan Keuangan Indonesia, $\quad 4(1), \quad$ 25-42. https://doi.org/https://doi.org/10. 23917/reaksi.v4i1.6935

Kusumawati, E., Permata Sari, S., \& Trisnawati, R. (2013). Pengaruh Asimetri Informasi dan Mekanisme Corporate Governance terhadap Praktik Earnings Management ( Kajian Perbandingan Perusahaan yang Terdaftar dalam Indeks Syariah dan Indeks Konvensional Bursa Efek Indonesia ). Proceeding Seminar Nasional Dan Call For Papers Sancall, 978-979.

Marzuqi, A. Y., \& Latif, A. B. (2010). Manajemen Laba dalam Etika Bisnis Islam. Jurnal Dinamika Akuntansi Dan Bisnis, 7(1), 1-22.

Muliasari, I., \& Dianati, D. (2014). Manajemen Laba Dalam Sudut Pandang Etika Bisnis Islam. Jumal Akuntansi Dan Keuangan Islam, 2(2), 157-182.

Negara, A. . G. R. P., \& Suputra, I. D. . D. 
(2017). Pengaruh Perencanaan Pajak Dan Beban Pajak Tangguhan Terhadap Manajemen Laba. E-Jurnal Akuntansi, 20, 2045-2072.

Nirwanan Sari, R., Tri Hardiyanto, A., \& Simamora, P. (2018). Pengaruh Beban Pajak Tangguhan, Perencanaan Pajak dan Profitabilitas Terhadap Manajemen Laba pada Perusahaan Manufaktur yang Terdaftar di Bursa Efek Indonesia Periode 2012-2017. Jurnal Online Mahasiswa (JOM), 5(5), 2.

Nurianah, N. (2019). What is earning management in sharia bank lower than conventional bank? Journal of Islamic Accounting and Finance Research, 1(1), 97. https://doi.org/10.21580/jiafr.2019. 1.1.3730

Octavia, E. (2017). Implikasi Corporate Governance dan Ukuran Perusahaan pada Manajemen Laba. Jurnal Akuntansi Multiparadigma, 8(1), 126136.

https://doi.org/http://doi.org/10.1 8202/jamal.2017.04.7044

Peraturan Otoritas Jasa Keuangan Nomor 55 /Pojk.04/2015 Tentang Pembentukan Dan Pedoman Pelaksanaan Kerja Komite Audit, Ojk.Go.Id 1 (2015).

Pohan, C. . (2013). Manajemen Perpajakan. PT Gramedia Pustaka Utama.

Prabowo, M. S. (2018). Dasar-Dasar Good Corporate Governance. UII Press.

Putri, B. . L., \& Rachmawati, S. (2018). Analisis Financial Distress dan Free
Cash Flow dengan Proporsi Dewan Komisaris Independen sebagai Variabel Moderasi Terhadap Manajemen Laba. Jurnal Keuangan Dan Perbankan, 14(2), 54-61.

Ross, S. A., Westerfield, R. W., Jordan, B. D., Lim, J., \& Tan, R. (2015). Fundamentals of Corporate Finance (C. Sasongko (ed.)). Salemba Empat.

Setyono, J. (2015). Good Governance Dalam Perspektif Islam (Pendekatan Ushul Fikih: Teori Pertingkatan Norma). Jurnal Muqtasid, 6(1), 25-40.

Sulistiyanto, S. (2008). Manajemen Laba: Teori dan Model Empiris. PT Grasindo.

Sutino, E. R. D., \& Khoiruddin, M. (2016). Pengaruh Good Corporate Governance terhadap Manajemen Laba pada Perusahaan yang Masuk dalam JII (Jakarta Islamic Index) Tahun 2012-2013. Management Analysis Journal, 5(3), 156-166. https://doi.org/https://doi.org/10. 15294/maj.v5i3.8274

Ulum, M., Agriyanto, R., \& Warno, W. (2020). Pengaruh Pengungkapan Emisi Gas Rumah Kaca terhadap Nilai Perusahaan dengan Biaya Lingkungan sebagai Variabel Moderasi. At-Taqaddum, 12(2), 155168.

Yogi, L. M. . P., \& Damayanthi, I. G. . E. (2016). Pengaruh Arus Kas Bebas, Capital Adequacy Ratio dan Good Corporate Governance pada Manajemen Laba. E-Jurnal Akuntansi Universitas Udayana, 15(2), 1056-1085. 
